\title{
LUXURY WINE: ANALYZING MOTIVATIONS OF LUXURY WINE BUYERS IN THE US MARKET
}

\author{
${ }^{1}$ Dr. Liz Thach, MW, ${ }^{2}$ Dr. Janeen Olsen \\ ${ }^{1}$ Distinguished Professor of Wine, Professor of Management \\ Sonoma State UniversityRohnert Park, California, USA \\ ${ }^{2}$ Professor of Wine Marketing Sonoma State University \\ Rohnert Park, California, USA
}

${ }^{1}$ Liz@lizthach.com,

2Janeenolsen@gmail.com

\begin{abstract}
The purpose of this research study was to describe motivations and demographics of luxury wine buyers in the US market. An online survey was completed by 1081 US wine consumers, of which 473 were designated to be luxury buyers based on price spent on wine. Standard demographic and wine consumer scales were utilized for profiling. Results show that the luxury wine buyer is more likely to be male, aged 30 to 50, with a higher income and education level. Motivations of the luxury wine buyer are different than the non-luxury wine buyer, and reasons for purchasing luxury wine go beyond mere collecting. This research is one of the first to analyze the luxury wine consumer in the US market, and provides useful information for wine marketers and researchers on the profile of the luxury wine buyer in America.
\end{abstract}

Keywords: Luxury Marketing, US Wine Market, Consumer Behavior, Agribusiness, Commerce. (JEL Classification: M31)

\section{INTRODUCTION}

The luxury market has been growing at a healthy pace for the past several decades, increasing from $€ 77$ billion in 1995 to $€ 253$ billion in 2015 (Bain, 2016). The growth is spurred by a variety of reasons, including globalization, cultural trends, luxury highlighted by the media, and the mounting number of wealthy people in the world (Seo and Buchanan-Oliver 2015; Kapferer and Bastien 2012).

As an agricultural product, wine has seen similar growth in luxury, primarily via luxury pricing, with the top fifty most expensive wines all priced at over $\$ 1,000$ per bottle, and the most expensive over $\$ 65,000$ per bottle, depending on vintage (WineSearcher, 2020). The trend is illustrated in increasing prices achieved at wine global auctions, with the Wine Spectator Auction Index showing over a 300\% increase in value from 1997 to 2015 (Wine Spectator, 2017).
The growth of the luxury wine market gives rise to questions regarding the types of consumers purchasing these high-priced wines and their reasons why. As the US is currently the largest wine consuming nation in the world in both quantity and value (Nielsen, 2017), a research study was designed to discover more about the type of consumer who purchases wine priced at over $\$ 50, \$ 100, \$ 200$, and $\$ 1000$. The results provide a demographic profile of the luxury wine buyer in America, as well as insights into their values and motivations for purchasing high-priced wines.

\section{REVIEW OF THE LITERATURE}

Luxury has been defined as "anything that is desirable and more than necessary and ordinary (Heine, 2013, p. 40)." The research literature also identifies several key attributes that define a luxury product. These include: high price, 
high quality with authenticity, a sense of scarcity, beautiful aesthetics that appeal to hedonists, providing a sense of privilege because it is special, and possessing a high degree of symbolism often derived from heritage (Vigneron and Johnson 2004; Kapferer and Bastien 2012; Hartman et al 2016; Sjostrom et al 2016; Beverland, 2005; Miller and Mills 2012; Dubois et al 2005; Hennigs et al 2012). More recently, the concept of sustainability has been added to the luxury criteria because of growing interest by consumers (Hartman et al 2016; Kapferer and Bastien 2012; Verain et al 2016).

There have been a variety of consumer behavior studies regarding luxury products, but most conclude that consumers differ by country and that not all of the luxury attributes listed above are important to all consumers (Hartmann et al, 2016; Heine et al 2014; Dubois et al 2005; Rod et al 2015; Hennigs et al 2012; Stiehler and Steihler 2016; Kapferer and Laurent 2016). For example in a study of 1275 consumers in 10 countries, the authors (Hennigs et al. 2012) found that that in the USA, India, Brazil and Italy consumers are more concerned with the hedonic, material, and affective aspects of luxury. German consumers were more interested in quality and performance, where French consumers valued luxury products because they were exclusive and high-priced. In the Czech Republic, researchers (Rod et al. 2015) analyzed demographic factors and found that younger, more highly educated consumers with higher incomes were more likely to buy luxury goods.

Despite difference by nationality, luxury researchers have developed several consumer luxury segmentations. In a large study of 1848 management students in 20 countries researchers (Dubois et al. 2005) were able to identify three types of luxury consumers: Elitists who believe luxury is only for the few; Democratic - who believe luxury is for the many; and Distant - who believe luxury is in a different world where they don't belong. A group of researchers (Heine et al. 2014) developed a simpler segmentation of: Aspirers who buy to enhance their social image and are price sensitive; and Connoisseurs who buy for enjoyment and sharing, and are not price sensitive. There is also a group of consumers who avoid luxury products, because they perceive them as wasteful (Dubois and Laurent 1994; Bryson et al. 2013). Another study (Wiedmann et al. 2009) of 750 consumers identified ten values associated with luxury: quality, uniqueness, sensory pleasure, aesthetics, excitement, hedonism, materialism, usability, selfidentify, and positive recognition from cohorts.

In the wine industry there have been several luxury research studies. One of the oldest was a study of 110 consumers in Australia (Beverland, 2004) where the findings showed that consumers used criteria such as high quality, handcrafted, proven track record, and ability to sell well at auction as important decision factors in luxury wine purchases. Interestingly they were not that concerned with the taste of the wine because many saved it in collections, which would later be sold, traded, or consumed on a special occasion. In a study of luxury wine producers in four different nations (Beverland, 2004b) results showed that producers were concerned with high quality, being authentic to what the land and vintage gave them to craft the wine, and having limited production. They primarily based their marketing message on heritage, family history, quality and scarcity. Additional research by Beveraland (2005, 2006) further highlighted the importance of authenticity for luxury wine and focusing on hand-crafted methods. Downplaying the use of technology in winemaking in order to be perceived as creating an authentically crafted product from the land was also identified in other luxury wine research studies (Heine et al. 2016). In the southern hemisphere, researchers (Sjostrom et al. 2016) found that higher-priced wine in the Australian market had five important elements: luxury, limited production/edition, antique/old (back vintage), premium price and premium.

Luxury wine is usually produced in a region known for its long history of fine wine production, and therefore has a sense of heritage and "sacred vineyards," such as Grand Cru designated vineyards in Burgundy (Yeung and Thach 2019). In addition, no expense is spared in the production of these wines, such as uses of the highest quality oak barrels for aging. Furthermore, they are generally distributed in a very careful manner, often utilizing an allocation system whereby restaurants, wine retailers, and end-consumers are only allowed to purchase a limited number of bottles each year (Beverland, 2005; Sjostrom et al. 2016).

Interestingly, luxury wine can be crafted as still dry, semi-sweet, or sweet wines, as well as sparkling wines. A major priority is that they have the ability to age, and can increase with price on the secondary market for trading (Yeung and Thach 2019; Beverland, 2004). Therefore, dry red Bordeaux or Napa Valley wines, dry white Burgundy, semi-sweet German Rieslings, sweet Madeira's or Ports, and sparkling Champagnes can all be classified as luxury wine as long as they meet the other criteria of high price, scarcity, heritage, ability to age, and so forth. Indeed, in a review of the top ten most expensive wines in the world, three are dry white wines; five are dry red wines; and two are sweet wines, including a German Trockenbeerenauslese Riesling from Egon Muller Scharzhofgerger winery and a J.S. Terrantez from Madeira, Portugal (Winesearcher.com, 2020). Of these, the most expensive is Domaine de la Romanee-Conti from the Romanee Conti Grand Cru vineyard in Burgundy, France at an average price of $\$ 20,708$ per bottle.

The concept of luxury wine pricing has also been examined in the research literature, but there is no conclusive agreement on the actual price point of luxury wine (see Table 1).

Table 1: Luxury Wine Pricing from Previous Studies

\begin{tabular}{|c|c|}
\hline Study & Pricing \\
\hline Geene (1999) & Icon wine as above $\$ 50$ \\
\hline Cholette and Castaldi (2005) & $\begin{array}{l}\text { Luxury } \$ 25 \text { to } \$ 50, \text { Super Luxury } \\
\$ 50 \text { to } \$ 100 \text {, and Icon over } \$ 100\end{array}$ \\
\hline Sjostrom et al (2014) & $\begin{array}{l}\text { Australian wine price segments: } \\
\$ 0-\$ 24.99, \$ 25-\$ 49.99, \$ 50- \\
\$ 99.99 \text {, and } \$ 100+\text {. }\end{array}$ \\
\hline Jarett and Jarvis (2016) & $\begin{array}{l}\text { Ultra-Premium wines \$70 - \$99 } \\
\text { AUD ( } \$ 51 \text { - \$72 USD); Luxury/ } \\
\text { Icon wines } \$ 100 \text { AUD ( } \$ 73 \text { USD) }\end{array}$ \\
\hline Brager (2016) & $\begin{array}{l}\text { Nielsen Wine Scan Data - Most } \\
\text { expensive is } \$ 25+\end{array}$ \\
\hline
\end{tabular}




\section{METHODOLOGY}

A quantitative research methodology was used to obtain an online sample of US wine consumers. The survey was developed using standard wine consumer scales, wine pricing, and demographic questions. A panel data provider, Survey Sampling International, was commissioned to collect a representative sample of American wine consumers by insuring that all 50 states were represented and that the gender matched US wine consumption statistics (Nielsen, 2016).

The survey was launched in the spring of 2016 over a two-week period. A total of 1081 usable surveys were received. Of these 473 consumers had purchased a bottle of wine for $\$ 50$ or more, which was used as a price point for luxury wine purchases, based on the literature review. Statistical analyses were performed on this portion of the sample using SPSS and Excel.

\section{RESULTS}

Gender - We first analyzed whether having purchased a bottle of wine over $\$ 50$ (Yes $=1$, No $=2$ ) and gender $($ Male $=1$, Female $=2)$ are independent of one another. A chi-square test of independence was performed. The relation between these 2 variables was significant, $\mathrm{X} 2(1, \mathrm{~N}=1081)$ $=30.97, \mathrm{p}<.000$. Luxury purchasers were more likely to be male (57.5\%) than female (42.5\%). The results of the crosstabs are reported in Table 2.

Table 2. Luxury Wine Buyer by Gender

\begin{tabular}{|c|c|c|c|c|c|}
\hline & & & & der & \\
\hline & & & Male & Female & \\
\hline & & Count & 246 & 362 & 608 \\
\hline & & $\begin{array}{l}\% \text { within } \\
\text { over } \$ 50\end{array}$ & $40.5 \%$ & $59.5 \%$ & $100.0 \%$ \\
\hline & & $\begin{array}{l}\% \text { within } \\
\text { gender }\end{array}$ & $47.5 \%$ & $64.3 \%$ & $56.2 \%$ \\
\hline Have you ever spent & & $\%$ of Total & $22.8 \%$ & $33.5 \%$ & $56.2 \%$ \\
\hline wine? & & Count & 272 & 201 & 473 \\
\hline & & $\begin{array}{l}\% \text { within } \\
\text { over } \$ 50\end{array}$ & $57.5 \%$ & $42.5 \%$ & $100.0 \%$ \\
\hline & Ies & $\begin{array}{c}\% \text { within } \\
\text { gender }\end{array}$ & $52.5 \%$ & $35.7 \%$ & $43.8 \%$ \\
\hline & & $\%$ of Total & $25.2 \%$ & $18.6 \%$ & $43.8 \%$ \\
\hline & & Count & 518 & 563 & 1081 \\
\hline & & $\begin{array}{l}\% \text { within } \\
\text { over } \$ 50\end{array}$ & $47.9 \%$ & $52.1 \%$ & $100.0 \%$ \\
\hline 10tal & & $\begin{array}{c}\% \text { within } \\
\text { gender }\end{array}$ & $100.0 \%$ & $100.0 \%$ & $100.0 \%$ \\
\hline & & $\%$ of Total & $47.9 \%$ & $52.1 \%$ & $100.0 \%$ \\
\hline
\end{tabular}

Income - Our second analysis looked at whether having spent over $\$ 50$ for a bottle of wine (Yes $=1$, No $=2$ ) and Income (9 ranges) are independent of one another. First, a chi-square test of independence was performed. The relation between these 2 variables was significant, $\mathrm{X} 2(8, \mathrm{~N}=1081)=92.33, \mathrm{p}<.000$. Luxury purchasers were more likely to be found in the upper income ranges, such as $\$ 70,000-\$ 99,999, \$ 100,000-\$ 149,999, \$ 150,000$ and $\$ 199,999$, and over $\$ 200,000$. A t-test was also run to determine if the mean between the 2 groups, those who spent over $\$ 50$ and those who never had, were different. The mean of 5.6 for those who had was significantly higher than the mean 4.4 for those that had not $\mathrm{T}(1079, \mathrm{~N}=$ $1081)=9.78, \mathrm{p}<.000$. Table $\mathrm{A} 1$ in the appendix describes these results in more detail.

Education Level - Our next analysis looked at whether having spent over $\$ 50$ for a bottle of wine (Yes $=1$, No $=$ 2 ) and Education (6 ranges) are independent of one another. First, a chi-square test of independence was performed. The relation between these 2 variables was significant, X2 $(5, \mathrm{~N}=1081)=25.43, \mathrm{p}<.000$. Luxury purchasers were more likely to be found among those that had graduated from college or completed their graduate degree, but interestingly not for those that had some graduate school but had not completed their degrees. The results of the cross tabs are reported in Table 2. A t-test was also run to determine if the mean for education between the 2 groups, those who spent over $\$ 50$ and those who never had, were different. The mean of 4.1 on the 6-point scale for those who had purchased was significantly higher than the mean 3.8 for those that had not, $\mathrm{T}(1079, \mathrm{~N}=1081)=4.03$, $\mathrm{p}<.000$. Table A2 in the appendix describes these results in more detail.

Age - Our final analysis for demographic variables considered whether having spent over $\$ 50$ for a bottle of wine (Yes $=1$, No $=2$ ) and age (5 ranges) are independent of one another. First, a chi-square test of independence was performed. The relation between these 2 variables was significant, $\mathrm{X} 2(4, \mathrm{~N}=1081)=28.70, \mathrm{p}<.000$. Luxury purchasers were more likely to be found among those in middle age categories, ages 30 to 50 . The results of the cross tabs are reported in Table 3 in the appendix. A t-test was also run to determine if the mean for age between the 2 groups, those who spent over $\$ 50$ and those who never had, were different. The mean of 3.1 on the 6-point scale for those who had purchased was significantly lower than the mean 3.3 for those that had not, $\mathrm{T}(1079, \mathrm{~N}=1081)$ $=4.03, \mathrm{p}<.000$.

Motivations - Next we analyzed whether having purchased a bottle of wine over $\$ 50($ Yes $=1$, No $=2$ ) and nine motivations for drinking wine (Yes $=1$, No $=$ 2) are independent of one another. A chi-square test of independence was performed. Due to space limitations, the crosstabs are not reported here for the nine motivations, but the findings are summarized in Table 5, with the six motivations that were significant listed first. 
Table 5: Luxury Wine Buyers and Motivations for Drinking Wine

\begin{tabular}{|c|c|c|}
\hline $\begin{array}{l}\text { Motivation (I drink } \\
\text { wine because...) }\end{array}$ & $\begin{array}{l}\text { Results of X2 analy- } \\
\text { sis - SIGNIFICANT }\end{array}$ & $\begin{array}{l}\text { Summary of Group Differ- } \\
\text { ences }\end{array}$ \\
\hline Wine tastes good & $\begin{array}{l}\mathrm{X}^{2}(1, \mathrm{~N}=1047)= \\
39.27, \mathrm{p}<.000\end{array}$ & $\begin{array}{l}\text { Luxury purchasers }(\mathrm{N}=476) \\
\text { were more likely to }(53.6 \%) \\
\text { than non purchasers }(\mathrm{N}= \\
671)(46.4) \text { to drink because } \\
\text { wine taste good. }\end{array}$ \\
\hline $\begin{array}{l}\text { Wine goes well } \\
\text { with food }\end{array}$ & $\begin{array}{l}\mathrm{X}^{2}(1, \mathrm{~N}=1047)= \\
74.73, \mathrm{p}<.000\end{array}$ & $\begin{array}{l}\text { Luxury purchasers }(\mathrm{N}=476) \\
\text { were more likely to }(53.6 \%) \\
\text { than non purchasers }(\mathrm{N}= \\
671)(46.4 \%) \text { to drink } \\
\text { because wine goes well with } \\
\text { food. }\end{array}$ \\
\hline $\begin{array}{l}\text { Wine helps me } \\
\text { relax }\end{array}$ & $\begin{array}{l}\mathrm{X}^{2}(1, \mathrm{~N}=1047)= \\
18.95, \mathrm{p}<.000\end{array}$ & $\begin{array}{l}\text { Luxury purchasers }(\mathrm{N}=476) \\
\text { were less likely to }(47.0 \%) \\
\text { than non purchasers }(\mathrm{N}= \\
671)(53.0 \%) \text { to drink be- } \\
\text { cause it helps them relax. }\end{array}$ \\
\hline $\begin{array}{l}\text { Wine helps me so- } \\
\text { cialize with friends }\end{array}$ & $\begin{array}{l}\mathrm{X}^{2}(1, \mathrm{~N}=1047)= \\
39.27, \mathrm{p}<.000\end{array}$ & $\begin{array}{l}\text { Luxury purchasers }(\mathrm{N}=476) \\
\text { were less likely to }(48.6 \%) \\
\text { than non purchasers }(\mathrm{N}= \\
671)(51.4 \%) \text { to drink be- } \\
\text { cause it helps them socialize } \\
\text { with friends. }\end{array}$ \\
\hline $\begin{array}{l}\text { Wine is for ro- } \\
\text { mance }\end{array}$ & $\begin{array}{l}\mathrm{X}^{2}(1, \mathrm{~N}=1047)= \\
35.96, \mathrm{p}<.000\end{array}$ & $\begin{array}{l}\text { Luxury purchasers }(\mathrm{N}=476) \\
\text { were more likely to }(60.6 \%) \\
\text { than non purchasers }(\mathrm{N}= \\
671)(39.4 \%) \text { to drink be- } \\
\text { cause wine is for romance. }\end{array}$ \\
\hline $\begin{array}{l}\text { I can analyze and } \\
\text { compare it with } \\
\text { friends }\end{array}$ & $\begin{array}{l}\mathrm{X}^{2}(1, \mathrm{~N}=1047)= \\
19,20, \mathrm{p}<.000\end{array}$ & $\begin{array}{l}\text { Luxury purchasers }(\mathrm{N}=476) \\
\text { were more likely to }(69.6 \%) \\
\text { than non purchasers }(\mathrm{N}= \\
671)(30.4 \%) \text { to drink be- } \\
\text { cause they can analyze and } \\
\text { compare wine with friends. }\end{array}$ \\
\hline
\end{tabular}

\begin{tabular}{|c|c|c|}
\hline $\begin{array}{l}\text { Motivation (I drink } \\
\text { wine because...) }\end{array}$ & $\begin{array}{c}\text { Results of } X^{2} \text { analysis } \\
\text { - NOT SIGNIFI- } \\
\text { CANT }\end{array}$ & $\begin{array}{l}\text { Summary of Group } \\
\text { Differences }\end{array}$ \\
\hline $\begin{array}{l}\text { Wine helps me social- } \\
\text { ize with family }\end{array}$ & $\begin{array}{l}\mathrm{X}^{2}(1, \mathrm{~N}=1047)= \\
6.97, \mathrm{p}<.008\end{array}$ & $\begin{array}{l}\text { Luxury purchasers } \\
(\mathrm{N}=476) \text { were less likely } \\
\text { to }(46.9 \%) \text { than non } \\
\text { purchasers }(\mathrm{N}=671) \\
(53.1 \%) \text { to drink because } \\
\text { wine helps them socialize } \\
\text { with family. }\end{array}$ \\
\hline For health reasons & $\begin{array}{l}X^{2}(1, N=1047)= \\
2.99, p=.084\end{array}$ & $\begin{array}{l}\text { Luxury purchasers } \\
(\mathrm{N}=476) \text { were no dif- } \\
\text { ferent }(46.9 \%) \text { than non } \\
\text { purchasers }(\mathrm{N}=671) \\
(53.1 \%) \text { to drink wine for } \\
\text { health reasons. }\end{array}$ \\
\hline Wine helps me sleep & $\begin{array}{l}\mathrm{X}^{2}(1, \mathrm{~N}=1047)= \\
1.17, \mathrm{p}=.280\end{array}$ & $\begin{array}{l}\text { Luxury purchasers } \\
(\mathrm{N}=476) \text { were no dif- } \\
\text { ferent }(45.7 \%) \text { than non } \\
\text { purchasers }(\mathrm{N}=671) \\
(54.3 \%) \text { to drink because } \\
\text { it helps them sleep. }\end{array}$ \\
\hline
\end{tabular}

Luxury Rationale - we also asked respondents the reason they purchased wine over $\$ 50$, providing four reasons and allowing them to select all that applied. Results are illustrated in Figure 1 and show that special occasions, selected by $60 \%$ of the luxury wine buyers, was the most important reason, followed by enjoyment $(53 \%)$, to give as a gift $(42 \%)$ and for their cellar $(12 \%)$.

Figure 1: Reasons for Buying Luxury Wine

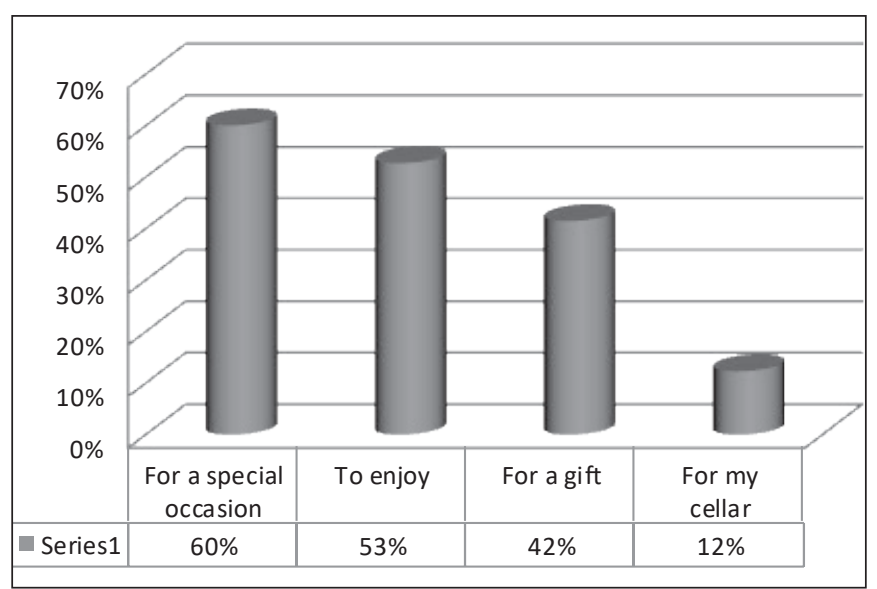

\section{DISCUSSION, LIMITATIONS AND FUTURE RESEARCH}

In analyzing the results of this research there are both expected and unexpected findings. As many would expect the demographic profile of the American luxury wine consumer is more likely to be male, aged 30 to 50, with a higher level of income and a bachelor's or graduate degree. Interestingly this supports older research on demographics of American wine consumers, though not luxury consumers (Wine Market Council, 2000).

What may be more interesting is that the luxury wine consumer is motivated not only by wine that tastes good and goes well with food, but is more interested than the non-luxury wine consumer in wine for romance, to socialize with friends, and to help with relaxation. He is also much more likely to drink wine because he enjoys analyzing it and comparing it with friends. This supports the findings of Beverland (2004), showing that luxury wine buyers often buy for their collection, rather than to drink the wine. However, though this study also showed that $12 \%$ of the luxury buyers did purchase for their cellar, 53\% were more concerned with enjoying the wine - perhaps in socializing with friends. This suggests that the American luxury wine buyer may be more interested in drinking wine in social circles, rather than just buying for a collection.

This study provides some implications for marketers in terms of consumer demographics they may want to profile in advertisements or online videos. It also highlights the need to focus on social occasions, including romance and comparing wine with friends. At the same time it has limitations in that it is based on a representative sample of American wine drinkers, rather than a random sample. In addition, the price point of wine over $\$ 50$ as luxury, may be too low. Given that wine is sold at much higher prices, future research may want to provide higher ranges and segment consumers based on these responses to see if the profile of the luxury 
consumer could be refined further. Finally other behavioral or psychographic scales could be used to further define the luxury wine consumer, as well as an analysis of the different styles of luxury wine they purchase, such as dry, semi-sweet, sweet, or sparkling.

\section{REFERENCES}

Bain (2016): Spring 2016 Luxury Market Report Update. Bain. com. May 24, 2016. Available at: http://www.bain.com/about/press/ press-releases/spring-luxury-update-2016.aspx

Beverland, M. (2005): Crafting Brand Authenticity: The Case of Luxury Wines. Journal of Management Studies, 42:1003-1029.

Beverland, M. (2006): "The 'real thing': Branding authenticity in the luxury wine trade.” Journal of Business Research 59.2: 251-258.

Beverland, M. B. (2004): An exploration of the luxury wine trade. International Journal of Wine Marketing, 16(3), 14-28.

Beverland, M., (2004b): Uncovering "theories-in-use": building luxury wine brands. European Journal of Marketing, 38(3/4), pp.446-466.

Brager, D. (2016): US Wine Consumer Trends - Battle for the Next Pour. 11th Annual Wine Market Council Research Conference on U.S. Wine Consumer Trends. Jan. 25, 2016. New York, NY.

Bryson, D., Atwal, G., Hultén, P., (2013): Towards the conceptualization of the antecedents of extreme negative affect towards luxury brands. Qualitative Market Research: An International Journal, 16(4), pp.393-405.

Cholette, S., Castaldi, R. (2005): Analyzing the US retail wine market using price and consumer segmentation models". 2nd International Wine Marketing Symposium, Sonoma State University, Rohnert Park, CA, 8-9 July, pp.1-27.

Dubois, B., Laurent, G. (1994): Attitudes towards the concept of luxury: An exploratory analysis. AP-Asia Pacific Advances in Consumer Research Volume 1.

Dubois, B., Czellar, S., Laurent, G., (2005): Consumer Segments Based on Attitudes Toward Luxury: Empirical Evidence from Twenty Countries. Marketing Letters, 16(2), pp.115- 128.

Geene, A., Heijbroek, A., Lagerwerf, A.; Wazir, R., (1999): The world wine business. Rabobank.

Hartmann, L. H., Nitzko, S., Spiller, A. (2016): The significance of definitional dimensions of luxury food. British Food Journal, 118(8), 1976-1998.

Heine, K. (2013): The Concept of Luxury Brands (Taxonomy \& Definition). White paper. Available at: http://www. conceptofluxurybrands.com/content/20121107_Heine_The-Conceptof-Luxury-Brands.pdf

Heine, K., Atwal, G., Ates, Z. (2014): Luxury wine marketing. Chapter in Wine Business Management, 235-246. Paris: Pearson.

Heine, K., Phan, M., Atwal, G., (2016): Authenticity and prestige: what luxury brands could learn from the wine industry? Luxury Research Journal, 1(2), pp.177-190.

Hennigs, N., Wiedmann, K.P., Klarmann, C., Strehlau, S., Godey,
B., Pederzoli, D., Neulinger, A., Dave, K., Aiello, G., Donvito, R. ,Taro, K., (2012): What is the Value of Luxury? A Cross-Cultural Consumer Perspective. Psychology \& Marketing, 29(12), pp.1018-1034.

Jarrett, S., Jarvis, W. (2016): Defining the luxury wine category via an assessment of price-tier perceptions. Refereed paper presented at 9th Academy of Wine Business Research Conference, Adelaide, Australia.

Kapferer, J. N., Laurent, G. (2016): Where do consumers think luxury begins? A study of perceived minimum price for 21 luxury goods in 7 countries. Journal of Business Research, 69(1), 332-340.

Kapferer, J.N Bastien, V. (2012): The luxury strategy: Break the rules of marketing to build luxury brands. London: Kogan Page Publishers.

Lazányi, J. (2008): Trends in wine production and trade. Applied Studies in Agribusiness and Commerce, 2(1-2), 137-146.

Miller, K.W. Mills, M.K., (2012): Probing brand luxury: A multiple lens approach. Journal of Brand Management, 20(1), pp.41-51.

Nielsen (2017): State of the Industry - What's Selling. Presentation by Danny Brager at Unified Wine Symposium. Sacramento, CA: Jan. 25, 2017.

Rod, A., Rais, J., Schwarz, J., (2015): Economics of Luxury-Who Buys Luxury Goods? 1. Economicky Casopis, 63(5), p.451.

Seo, Y. Buchanan-Oliver, M., (2015): Luxury branding: the industry, trends, and future conceptualizations. Asia Pacific Journal of Marketing and Logistics, 27(1), pp.82-98.

Sjostrom, T., Corsi, A.M., Lockshin, L., (2016): What characterizes luxury products? A study across three product categories. International Journal of Wine Business Research, 28(1), pp.76-95.

Stiehler, B.E., Stiehler, B.E., (2016): Co-creating luxury brands in an emerging market: Exploring consumer meaning making and value creation. Qualitative Market Research: An International Journal, 19(4), pp.395-415.

Yeung, P \& Thach, L. (2019): Luxury Wine Marketing: The Art and Science of Luxury Wine Branding. Oxford: Infinite Ideas.

Verain, M. C., Onwezen, M. C., Sijtsema, S. J., Dagevos, H. (2016): The added value of sustainability motivations in understanding sustainable food choices. APSTRACT: Applied Studies in Agribusiness and Commerce, 10(2-3), 67-76.

Vigneron, F., \& Johnson, L. W. (2004): Measuring perceptions of brand luxury. Journal of brand management, 11(6), 484-506.

Wiedmann, K. P., Hennigs, N., Siebels, A. (2009): Value-based segmentation of luxury consumption behavior. Psychology \& Marketing, 26(7), 625-651.

Winemarket Council (2000): Wine Market Annual American Wine Consumer Research Report. January 2000.

WineSearcher (2020): The World's Top 50 Most Expensive Wines. Winesearcher.com. Retrieved on Jan. 30, 2020 at http://www.winesearcher.com/most-expensive-wines

WineSpectator (2017): Wine Spectator Auction Index. Winespectator. com. Available at: http://www.winespectator.com/display/show/id/ auction_index 


\section{APPENDIX}

\begin{tabular}{|c|c|c|c|c|c|c|c|c|c|c|c|c|}
\hline & & & \multicolumn{10}{|c|}{ Approximate annual household income before taxes } \\
\hline & & & $\begin{array}{l}\text { Less than } \\
\$ 20,000\end{array}$ & $\begin{array}{c}\$ 20,000- \\
\$ 29,999\end{array}$ & $\begin{array}{c}\$ 30,000- \\
\$ 39,999\end{array}$ & $\begin{array}{c}\$ 40,000- \\
\$ 49,999\end{array}$ & $\begin{array}{c}\$ 50,000- \\
\$ 69,999\end{array}$ & $\begin{array}{c}\$ 70,000- \\
\$ 99,999\end{array}$ & $\begin{array}{c}\$ 100,000 \\
- \\
\$ 149,999\end{array}$ & $\begin{array}{c}\$ 150,000 \\
\text { and } \\
\$ 199,999\end{array}$ & $\begin{array}{c}\text { Over } \\
\$ 200,000\end{array}$ & Total \\
\hline \multirow{8}{*}{$\begin{array}{c}\text { Have you } \\
\text { spent over } \\
\$ 50 \text { for a bot- } \\
\text { tle of wine? }\end{array}$} & \multirow{4}{*}{ No } & Count & 77 & 73 & 76 & 65 & 105 & 106 & 77 & 20 & 9 & 608 \\
\hline & & $\begin{array}{l}\% \text { within } \\
\text { over } \$ 50\end{array}$ & $12.7 \%$ & $12.0 \%$ & $12.5 \%$ & $10.7 \%$ & $17.3 \%$ & $17.4 \%$ & $12.7 \%$ & $3.3 \%$ & $1.5 \%$ & $100.0 \%$ \\
\hline & & $\begin{array}{l}\% \text { within } \\
\text { annual } \\
\text { household } \\
\text { income }\end{array}$ & $80.2 \%$ & $72.3 \%$ & $75.2 \%$ & $58.6 \%$ & $58.0 \%$ & $48.2 \%$ & $43.5 \%$ & $37.0 \%$ & $22.5 \%$ & $56.2 \%$ \\
\hline & & $\%$ of Total & $7.1 \%$ & $6.8 \%$ & $7.0 \%$ & $6.0 \%$ & $9.7 \%$ & $9.8 \%$ & $7.1 \%$ & $1.9 \%$ & $0.8 \%$ & $56.2 \%$ \\
\hline & \multirow{4}{*}{ Yes } & Count & 19 & 28 & 25 & 46 & 76 & 114 & 100 & 34 & 31 & 473 \\
\hline & & $\begin{array}{l}\% \text { within } \\
\text { over } \$ 50\end{array}$ & $4.0 \%$ & $5.9 \%$ & $5.3 \%$ & $9.7 \%$ & $16.1 \%$ & $24.1 \%$ & $21.1 \%$ & $7.2 \%$ & $6.6 \%$ & $100.0 \%$ \\
\hline & & $\begin{array}{l}\% \text { within } \\
\text { Annual } \\
\text { household } \\
\text { income }\end{array}$ & $19.8 \%$ & $27.7 \%$ & $24.8 \%$ & $41.4 \%$ & $42.0 \%$ & $51.8 \%$ & $56.5 \%$ & $63.0 \%$ & $77.5 \%$ & $43.8 \%$ \\
\hline & & $\%$ of Total & $1.8 \%$ & $2.6 \%$ & $2.3 \%$ & $4.3 \%$ & $7.0 \%$ & $10.5 \%$ & $9.3 \%$ & $3.1 \%$ & $2.9 \%$ & $43.8 \%$ \\
\hline \multirow{4}{*}{ Total } & Count & 96 & 101 & 101 & 111 & 181 & 220 & 177 & 54 & 40 & 1081 & \\
\hline & $\begin{array}{l}\% \text { within } \\
\text { over } \$ 50\end{array}$ & $8.9 \%$ & $9.3 \%$ & $9.3 \%$ & $10.3 \%$ & $16.7 \%$ & $20.4 \%$ & $16.4 \%$ & $5.0 \%$ & $3.7 \%$ & $100.0 \%$ & \\
\hline & $\begin{array}{l}\% \text { within } \\
\text { annual } \\
\text { household } \\
\text { income }\end{array}$ & $100.0 \%$ & $100.0 \%$ & $100.0 \%$ & $100.0 \%$ & $100.0 \%$ & $100.0 \%$ & $100.0 \%$ & $100.0 \%$ & $100.0 \%$ & $100.0 \%$ & \\
\hline & $\%$ of Total & $8.9 \%$ & $9.3 \%$ & $9.3 \%$ & $10.3 \%$ & $16.7 \%$ & $20.4 \%$ & $16.4 \%$ & $5.0 \%$ & $3.7 \%$ & $100.0 \%$ & \\
\hline
\end{tabular}

Table A2: Luxury Wine Buyer and Education

\begin{tabular}{|c|c|c|c|c|c|c|c|c|c|}
\hline & \multicolumn{6}{|c|}{ Highest level of formal education } & \multirow[b]{2}{*}{ Total } \\
\hline & & & $\begin{array}{c}\text { Some high } \\
\text { school or less }\end{array}$ & $\begin{array}{l}\text { High school } \\
\text { graduate }\end{array}$ & Some college & $\begin{array}{l}\text { College } \\
\text { graduate }\end{array}$ & $\begin{array}{l}\text { Some gradu- } \\
\text { ate school }\end{array}$ & $\begin{array}{l}\text { Completed } \\
\text { graduate school }\end{array}$ & \\
\hline \multirow{8}{*}{$\begin{array}{l}\text { Have you ever } \\
\text { spent over } \$ 50 \\
\text { for a bottle of } \\
\text { wine? }\end{array}$} & \multirow{4}{*}{ No } & Count & 6 & 92 & 165 & 206 & 37 & 102 & 608 \\
\hline & & $\begin{array}{c}\% \text { within over } \\
\$ 50\end{array}$ & $1.0 \%$ & $15.1 \%$ & $27.1 \%$ & $33.9 \%$ & $6.1 \%$ & $16.8 \%$ & $100.0 \%$ \\
\hline & & $\begin{array}{l}\% \text { within educa- } \\
\text { tion }\end{array}$ & $85.7 \%$ & $71.3 \%$ & $60.4 \%$ & $51.0 \%$ & $60.7 \%$ & $49.3 \%$ & $56.2 \%$ \\
\hline & & $\%$ of Total & $0.6 \%$ & $8.5 \%$ & $15.3 \%$ & $19.1 \%$ & $3.4 \%$ & $9.4 \%$ & $56.2 \%$ \\
\hline & \multirow{4}{*}{ Yes } & Count & 1 & 37 & 108 & 198 & 24 & 105 & 473 \\
\hline & & $\%$ within over $\$ 50$ & $0.2 \%$ & $7.8 \%$ & $22.8 \%$ & $41.9 \%$ & $5.1 \%$ & $22.2 \%$ & $100.0 \%$ \\
\hline & & $\begin{array}{l}\% \text { within educa- } \\
\text { tion }\end{array}$ & $14.3 \%$ & $28.7 \%$ & $39.6 \%$ & $49.0 \%$ & $39.3 \%$ & $50.7 \%$ & $43.8 \%$ \\
\hline & & $\%$ of Total & $0.1 \%$ & $3.4 \%$ & $10.0 \%$ & $18.3 \%$ & $2.2 \%$ & $9.7 \%$ & $43.8 \%$ \\
\hline \multirow{4}{*}{\multicolumn{2}{|c|}{ Total }} & Count & 7 & 129 & 273 & 404 & 61 & 207 & 1081 \\
\hline & & $\%$ within over $\$ 50$ & $0.6 \%$ & $11.9 \%$ & $25.3 \%$ & $37.4 \%$ & $5.6 \%$ & $19.1 \%$ & $100.0 \%$ \\
\hline & & $\begin{array}{l}\% \text { within educa- } \\
\text { tion }\end{array}$ & $100.0 \%$ & $100.0 \%$ & $100.0 \%$ & $100.0 \%$ & $100.0 \%$ & $100.0 \%$ & $100.0 \%$ \\
\hline & & $\%$ of Total & $0.6 \%$ & $11.9 \%$ & $25.3 \%$ & $37.4 \%$ & $5.6 \%$ & $19.1 \%$ & $100.0 \%$ \\
\hline
\end{tabular}


Table A3: Luxury Wine Buyer and Age

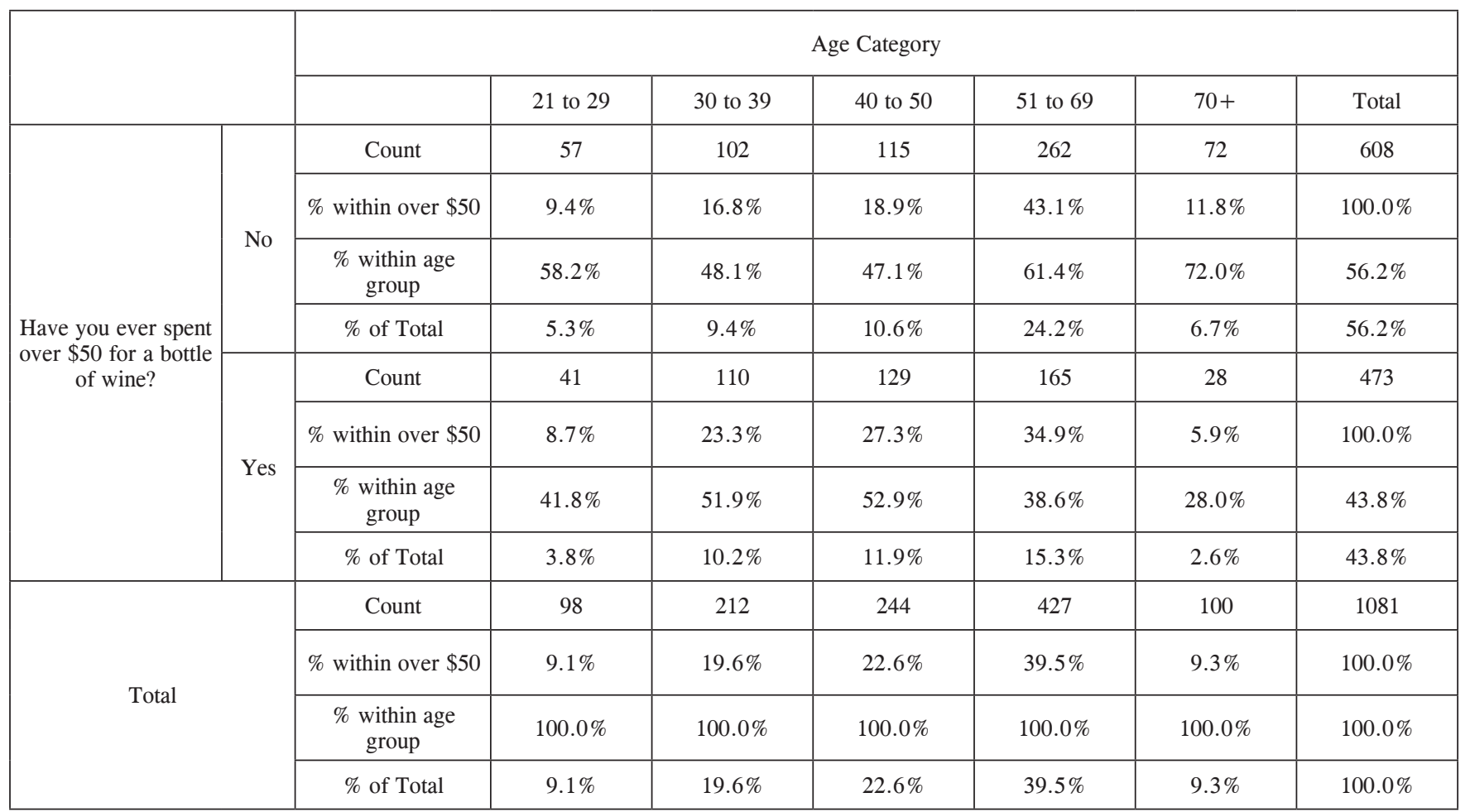


